\title{
KAMU BORÇLANMA (İSTİKRAZ) SÖZLEŞMELERİ
}

\author{
Cihan KANLIGÖZ*
}

\section{GENEL OLARAK KAMU BORÇLANMALARI}

Devlet ve diğer kamu tüzel kişileri ihtiyaç duyduklan paraları piyasalardan ya da doğrudan vatandaşlardan borç almak sureti ile de temin edebilirler.

Klasik maliye teorisi, borçlanmayı devletlerin olağan finansman yöntemleri arasında kabul etmemekte ${ }^{1}$ ve kural olarak Devletin borçlanmasına karşı tavır almaktaydı. Klasik maliye anlayışına göre ancak normal kamu gelirlerinin kamu hizmetlerini karşılamakıa yetersiz kalması halinde; köprü, baraj, demiryolları yapımı gibi gelecek nesillerin de yararlanacağı hizmetler ile savaş ve benzeri olağanüstü hallerde borçlanma yoluna gidileceği kabul ediliyordu² 2

Günümüzde ise hemen hemen bütün Devletlerin, büyük yatırımlar ya da savaşlar dışında, yıllık bütçe açıklarını kapatmak için de gittikçe artan ollçülerde borçlanmalara başvurduklan görülmektedir ${ }^{3}$.

Gerçekten de, günümüzde devletlerin yüklenmiş olduğu hizmetlerin artması, sosyal devlet anlayışının bir sonucu olarak klasik devlet görevlerinin yanında ekonomik ve toplumsal sorunlara da çözüm getirme zorunluluğu ve ozellikle alt yapının yenilenmesi ve geliştirilmesi faaliyetleri, devletleri i̧̧ ve dış borçlanmaya zorlamaktadır. Yeni barajlar, demir yolları, hava meydanlan, limanlar yapılması, sanayii işletmelerinin kurulması, modern teknoloji gerektiren haberleşme hizmetleri, silahlanma ve uzay yanşı gibi çeşitli nedenlerle büyük ölçüde artı̧ gösteren devlet giderleri normal devlet gelirleri ile karşılanamamakta ve devletler daha fazla į̧ ve dış borçlanma gereksinimi

\footnotetext{
* A.U. Hukuk Fakültesi, Idare Hukuku Anabilim Dalı Araşturma Görevlisi.

1Nadaroğlu, H., Kamu Maliyesi Teorisi, Istanbul 1985, sh. 240.

${ }^{2}$ Erginay, A., Kamu Maliyesi, Ankara 1983, sh. 12; Nadaroğlu, H., a.g.e., sh. 240; Ince, M., Devlet Borçlanması (Kamu Kredisi), Ankara 1996, sh. 27.

3 Ince, a.g.e., sh. 19; Nadaroğlu, a.g.e., sh. 240; Yaşa, M., Devlet Borçlan, Ankara 1978, sh. 10 .
} 
duymaktadırlar 4 . Bu nedenlerle günümüzde, borçlanmada vergi gelirleri gibi Devletin olağan gelir türleri arasında kabu.l edilmekte ve Devletlerin normal sartlar alunda da borçlanma yoluna gidebileceği göriş̧ü benimsenmektedir 5 .

Eski devirlerde Devletin tekelinde bulunan para basma imtiyazının, günümüzde Merkez Bankalarna devredilmiş olması da Devleulerin borçlanmaya gitmesinde önemli bir etken olarak karşımıza çıkmaktadır ${ }^{6}$.

Devletler borçlanmayı dış devlet ve piyasalardan yapabilecekleri gibi, ihtiyaç duyduklan paraları iç piyasa ve kuruluşlardan da sağlayabilirler. Devletin başka devletlerle veya kuruluşlarla yaptığı borçlanma sơzleşmıleri, esas itibarıyla, devletler hukuku kurallarına göre düzenlendiği ve hukuki nitelikleri bakımından iç borçlanmalara gơre farklı unsurlar içerdiği için ${ }^{\xi}$, burada sadece kamu iç borçlanmalan inceleme konusu yapılacakur.

\section{KAMU HARCAMALARI ILE ÖZEL BORÇLANMALAR ARASINDAKI FARKLAR}

Devlet ve diğer kamu tüzel kişilerince gerçekleştirilen kamu borçlanmalan çeşitli açılardan ozzel borçlanmalardan ayrilır: Birinci olarak, ozel borçlanmalar daha çok bir ticari, sınai, zirai veya mesleki faaliyetin yürütülmesi ya da geliştirilmesi için ve boŗ̧ alan kişinin ozzel yaran gözetilerek; kar amacı ile yapıldıklan halde, kamu borçlanmaları kamu yararı gözetilerek ve kamu hizmetlerinin yürütülmesi için yapılır. Kamu borçlanmasında maliyet ve karlılık gibi faktörler aranmayacă̆ı gibi, kamu hizmeti dışında başka bir amaç da sózkonusu olamaz ${ }^{8}$.

Ikinci olarak, kamu borçlanmaları geri ödeme süreleri bakımından ozel borçlanmalardan ayrılırlar. Devlet ve diğer kamu tüzel kişilerince yapılan borçlanmalar geneilikle alt yapı yatırımlarının finansmanı için yapıldığından bu borçların odeme süresi de oldukça uzundur. Bu süre 100 yıla kadar varabilmekte; hatta ödeme süresi belli olmayan borçlanmalar görülmektedir. Oysa özel borçlanmalar genel olarak kısa vadelidir ve bu süre çoğunlukla bir yılı geçmez ${ }^{9}$.

Kamu borçlanmalan ile özcl borçlar arasındaki bir diğer fark, borçlanma miktan açısından ortaya çıkmaktadır. Gerçekten, Devlet ve diğer kamu tüzel kişilerinin yapuklan borçlanmalar, ozel kişilerin borçlanmalarına göre çok daha büyük miktarlara ulaşmaktadır. Ozzel şahıs ve şirketlerin borçlanmalan sermayeleri, ciroları ve karları ile

${ }^{4}$ Ozer, 1., Devlet Maliyesi, ankara 1980, sh. 122, 125; Arsan, O., Türkiye'de Cumhuriyet Devrinde Iç Devlet Borçları, Ankara 1961, sh. 13.

5 Ozer, a.g.e., sh. 125.

${ }^{6}$ Gerçekten de Devlet, Merkez Bankası uzzerindeki etkisini kullanarak Merkez Bankasına para bastırabilmekte ise de bu kaynaktan faydalanma Merkez Bankasına borçlanmak sureti ile olmaktadır. Arsan, U., a.g.e., sh. 14.

${ }^{7}$ Bkz. Yayla, Y., Idare Hukuku I, Istanbul 1990, sh. 126, dipnot 129.

${ }^{8}$ Ozer, a.g.e., sh. 122; Ince, a.g.e., sh. 21.

${ }^{9}$ Ince, a.g.e., sh. 21-22; Ozer, a.g.e., sh. 122; 
orantılı olarak büyümekle birlikte, hị̧ bir kişi ya da teşebbüsün ekonomik güç yơnünden Devletin düzeyine ulaşamayacağ açıkur $^{10}$.

Son olarak kamu borçlanmalan iç ve dış kaynaklardan yapılabildiği halde, òzel borçlanmalar istisnalar dışında, genellikle iç kaynaklardan yapulırlar ${ }^{11}$.

\section{KAMU BORÇLANMALARININ HUKUKI YAPISI}

Devlet ve kamu tüzel kişileri, iç borçlanma amacıyla siyasi sınırlar içindeki çeşitli kuruluşlara ya da gerçek kişilere başvurabilirler. Devlet ve diğer kamu tüzel kişilerince gerçekleştirilen borçlanmalarda, esas olarak, hazine bonosu ya da devlet tahvili gibi adlarla çıkarılan borçlanma senetlerinin kullanıldı̆̆ın görmekteyiz ${ }^{12}$.

Her borçlanma işleminde olduğu gibi, Devlet borçlannda da genel ilke, kişi ve kurumların kendi istekleriyle Devlete borç vermeleridir ${ }^{13}$. Borçlanma işlemi kural olarak, kişilerin serbest irade ve arzuları ile ve herhangi bir zorlama olmaksızın borç vermeleri suretiyle gerçeklcştirilir. Bu anlamda, Devlet ve diğer kamu tüzel kişilerince gerçekleştirilen borçlanmalar da bir sőzleşme ile yapılmakta ve bütün sőzleşmelerde olduğu gibi iki taraflı bir nza ile bağıtlanmaktadırlar. Bununla birlikte bu sözleşmeler, özel hukukta görmüş olduğumuz boŗ̧ aktinden farklı olarak, koşullanı özel bir kanunla belirtilmiş olan ve kamu hukukuna giren sözleşmelerdir ${ }^{14}$.

Bu şekilde; devlet ve diğer kamu tüzel kişilerince, tahvil, bono ve benzeri adlarla çıkarılan senetler karşılığında halktan ve piyasalardan borç para alınmasını sağlayan sơzleşmelere kamu borçlanma (istikraz) sözleşmesi denilmekıedir ${ }^{15}$.

Kamu borçlanma sơzleşmeleri, Türk Hukuk Doktrini ve yargısal içtihatlarında, bu sőzleşmelerin konularını ठzzellił̆i gereği olarak, ozel hukuk sőzleşmelerinden farklı, idari (Kamusal) niteliğe haiz sözleşmeler olarak kabul edilmektedir. Danıştayın bu konuya ilişkin bir kararında da belirtildiği üzere; "Devlet istikrazlanı hukuku amme kavaidi ile vücud bulan bir borç olmak itibanyle" idari netilektedir ${ }^{16}$.

Isteğe bağlı borçlanma imkanlarının azaldığı, özellikle savaş gibi olağanüstü donemlerde, devletlerin cebir kullanarak kişi ve kurumlara borçlanma yoluna gittigine de

${ }^{10}$ Ince, a.g.e., sh. 21 ; Özer, a.g.e., sh. 122;

11 Ozer, a.g.e., sh. 123. Bununla birlikte son yıllarda özel kesimin de gittikçe artan oranlarda dı̧ borçlanma yoluna gittiği görülmektedir.

12 Ince, a.g.e., sh. 54, 215; Bununla birlikte uygulamada istisnai de olsa bazı durumlarda "Muttehhit Bonoları, Kefalet Bonoları ve Olağanüstủ Durum Bonoları" gibi adlarla borçlanma senetleri çıkarılmışır. Bkz. Evgin. T., "90'lı Yıllarda Iç Borçlarımızın Ekonomik Açıdan Değerlendirilmesi", A.U. SBFD., Prof. Dr. Latif Çakıcı'ya Armağan, sh. 210, 213, Ayrica bkz. Arsan, a.g.e., sh. $37 \mathrm{vd}$.

13 Yaşa, a.g.e., sh. 47; Ozer, a.g.e., sh. 134.

${ }^{14}$ Ozer, a.g.e., sh. 124; tnce, a.g.e., sh. 27.

15 Duran, Ders Notları, sh. 428; Onar, S.S., Idare Hukukunun Umumi Esaslan, Istanbul 1966, sh. 1592; Günday, M. Idare Hukuku, Ankara 1996, sh. 137.

${ }^{16}$ Da. DDGK., E. 38/375, K. 44/54 sayılı kararı, DKD., sa. 27, sh. 39. 
rastlanmaktadır ${ }^{17}$. Bu durumda borç verme, kişi ve kurumlann serbest iradelerine dayanmamakta, devlet tarafından cebri tasarruf yaraulmak ya da mevcut tasarruflara el konulması suretiyle kişi ve kurulışlara borçlanılması yoluna gidilmektedir. Zorlayışlı (cebri) borçlanma olarak da adlandırılan bu uygulamaya, özellikle II. Dünya Savaşı yıllarında Savaş'ın finansmanı için ve daha sonra da bu Savaşín yol açuğı yıkıntıların onarilması amacı ile Îngilıere, Kanada, A.B.D. ve Fransa gibi ülkeler tarafından yoğun olarak başvurulduğu görülmüştür:. Örneğin; 1942-1945 yıllan arasında Ingiltere'de, 1942'de Kanada'da, 1948'de Fransa'da ve yine II. Dünya Savaşı yıllarında A.B.D.'nde cebri borçlanmalara başvurulmuştur ${ }^{18}$.

Ülkemizde de 5 Ocak 1961 tarih ve 223 sayılı Yaturımlar Finansman Fonu Teşkil ve Tasaruf Bonoları thraci Hakkında Kanun'la ${ }^{19}$ uygulamaya konulan "Lasarruf bonolari" sistemi Devlet tarafından cebren borçlanma yönteminin bir ömeğini teşkil etmekteydi ${ }^{20}$. Aynı şekilde, Ülkemizde 9 Mart 1988 tarih ve 3417 sayılı Çalışanların Tasarrufa Teşvik Edilmesi ve Bu Tasarrufların Değerlendirilmesine Dair Yasa 21 ile getirilen ve halen uygulanmakta olan "Çalışanların Tasarruflanını Teşvik Fonu" da niteliği bakımından bir cebri borçlanma olarak kabul edilebilir ${ }^{22}$. Son olarak yine 3182 sayılı Bankalar Kanunu'nun ${ }^{23}$ 33. maddesi ile bankalara; Türk Ticaret Kanunu'nun 466 ve 467 . maddeleri ve Bankalar Kanunu'nun 32. maddesi uyarınca, muhtemel zarar karşılığı olarak ayıracakları yedek akçelerinin tamamını, T.C. Merkez Bankası nezdinde Hazine adına açılacak Devlet Tahvili Hesabına yaurma zorunluluğu getirilmiş olması da Devlet tarafından gerçekleştirilen bir ccbri borçlanma olarak kabul cdilebilir ${ }^{24}$.

17 Ozer, a.g.e., sh. 134.

18 Ince, a.g.e., sh. $200 \mathrm{vd}$;; Yaşa, a.g.e., sh. 49.

${ }^{19}$ Bkz. 12 Ocak 1961 tarih ve 10705 sayılı R.G.

${ }^{20}$ Yaşa, a.g.e., sh. 49; Ince, a.g.e., sh. 205; Özer, a.g.e., sh. 134, 135. Sözkonusu yatırımlar Finansman Fonu'Teskil ve. Tasarruf Bonoları Ihracı hakkında Kanun 26 Haziran 1972 tarih ve 1598 sayil Mali Denge Vergisi Kanunu'nun 14 üncù maddesi ile yurürlukten kald̛rımıştır.

${ }^{21}$ Bkz. 18.3.1988 tarih ve 19758 sayılı R.G.

22 Bkz. Ince, a.g.e., sh. 211. Sözkonusu Yasanın 3. maddesine göre çalı̧̧anlar ve işverenlerinden "tasarruf kesintisi" adı alıda bir kesinti yapılmaktadır. Bu kesinti çalışanların aylık ve ücretlerinin \% 2'si ile Devlet ve işverence yapılacak \% 3 nispetindeki katkı payından oluşmaktadır. Ayrıca tasarruf kesintisinin nisbetini \% 4 'e, Devlet ve işveren katkısının nispetini \% 6'ya yükseltmeye Bakanlar Kurulu yetkili kılınmıştır. 23.12.1988 tarih ve 88/13637 sayılı Bakanlar Kurulu Karanyla 15.1.1989 tarihinden geçerli olmak uzere, Kanunla tesbit edilen $\% 2$ ve $\% 3$ nisbetindeki kesinti ve katkı oranlan sırasıyla $\% 3$ ve $\% 4.5$ olarak belirlenmiştir. Ne zaman geri ödeneceği ve ne kadar faiz verileceği belli olmayan bu kesintiler süresiz cebri borçlanma olarak kabul edilebilir. Bkz. Ince, a.g.e., sh.

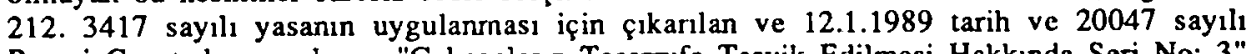
Resmi Gazetede yayınlanan "Çalı̧̧anların Tasarrufa Teşvik Edilmesi Hakkunda Seri No: 3" sayılı Tebliğin iptali için Tưrk- Is tarafından Danıştay'a açılan davada Danıştay 3417 sayılı Yasanın Anayasaya aykınılığı iddiasını ciddi bulmayarak bu istemi ve iptal davasını reddetmiştir. Bkz. 10 D. E.1989/783, K. 1992/1251, Dan. D. sa. 86, sh. 506.

232 Mayıs 1985 tarih ve 18742 sayılı R.G.

${ }^{24}$ Aynı doğrultuda bkz. Ince, a.g.e., sh. 212. 
Cebri borçlanma ile Devlet, kişi ve kurumlan belli miktarlarda devlet tahvili (ya da bonosu) almaya zorlamaktadır ${ }^{25}$. Bu şckilde bir borçlanma kişilerin serbest iradesine dayanmadığı için aktî nitelikte bir borç ilişkisinden ziyade, Devletin egemenlik gücünden kaynaklanan, vergi benzeri bir hukuki ilişki doğurduğu söylenebilir ${ }^{26}$. Ancak vergilerin kesin ve karşılıksız bir finansman yőntemi olmasına karşılık Devlet cebren el koymuş olduğu bu tasarruflara belli bir faiz oddemekte ve vadesi geldiğinde iade edeceğini taahhüt etmektedir.

Devletin bu şekilde, cebri tasarruf yaratması ya da kişi ve kurumlarca onceden çeşitli şekillerde oluşturulmuş olan tasarruflara el koyması işleminin hukuki niteliži, oğretide tartışmalara konu olmuştur. Bu konuda oğretide, sర̋z konusu işlemin esas itibarı ile bir borçlanma işlemi olduğu; bu işlemin kişilerin serbest iradesine dayanmaması, borç verecek şahısların ve verilecek borç miktarının Devletçe belirlenmesi nedeni ile işlemin vergilere yaklaşı̆̆ı̆ ancak; borç veren kişilere borç süresi içinde faiz ve vade sonunda da borcun ơdenmesinin ise borçlanmaya benzer noktalan oluşturduğu, genel olarak kabul edilmcktedir ${ }^{27}$. Nitekim, bu konuda görüş belirten yazarlardan Ince'ye göre: "...zorlayış̧ı (cebri) borçlanmaların da, bir akit olduğu kabul edilmekle birlikte, çok kez faiz oranlarının düşük oluşu ve prim, ikramiye gibi para ile ilgili çıkar sağlamamaları , yönünden vergiye yaklaşuğı kabul edilmektedir" 28 .

Ancak hemen belirtmek gerekir ki, biz burada aktî bir ilişkiden ve dolayısı ile cebren de olsa bir borçlanmadan söz edilmesinin mümkün olamayacağı görüşündeyiz. Gerçekten de borçlanma esas olarak bir aktî ilişki neticesinde gerçckleştirildiğine ve bir aktî iliş̧iden söz edilebilmesi için ise; işlemin tarafların serbest ve birbirine uygun iradeleri ile gerçekleştirilmesi gerektiǧine göre ${ }^{29}$, cebri tasarruf yaratarak ya da mevcut tasarruflara Devletin cebren elkoyması sureti ile gerçekleştirilen işlem, akt̂́ bir ilişki ve dolayısı ile bir borç ilişkisi olarak kabul edilemez.

Devletin, kişi ve kurumlann tasarruflanna cebren elkoymasında karşılıklı bir rıza olmadığı gibi, cl konulan tasarruflara faiz. odenmesi ve bunların belirli bir süre sonunda iade edilmesi de bu işlemin aktî bir iliş̧ki, dolayısı ile bir borçlanma işlemi niteliğinde olduğunu göstermez. Çünkü oddenen faiz ve geri ödeme süresi taraflann karşıılıklı iradeleri ile bağııllanmış bir sơzzleşmeye değil, Devletin tek tararflı iradesine, tabir caizse lütfuna bağlı tutulmuştur. Gerçi aşağıda da göreceğimiz üzere, isteğe bağlı kamu borçlanma sözleşmelerinde de Devlet ve diğer kamu tüzel kişilerinin, faiz ve anaparaya ilişkin olarak sözleşme koşullarını sonradan tek taraflı olarak değiştirebilme konusunda üstün yetki ve

${ }^{25}$ Cebri borçlanmada, Devletin tahvil veya bonolanını satacağı kimseler ve bunların almaları gereken senet miktan genellikle kişilerin gelir ve servetlerine göre önceden belirlenmektedir. Böylece belli bir düzeyin altında gelir ve serveti olanlar bu işlemden muaf tutulmakta, bunlanın dışında kalanlar için belirlenen miktarlarda tahvil veya bono alma zorunluluğu getirilmektedir. Bkz. Ince, a.g.e., sh. 200.

${ }^{26}$ Nadaroğlu, a.g.e., sh. 239-240; Ince, a.g.e., sh. 200.

27 Ozer, a.g.e., sh. 134; Ince, a.g.e., sh. 27-200; Yaşa, a.g.e., sh. 47-48.

${ }^{28}$ Bkz. Ince, a.g.e., sh. 27.

${ }^{29}$ Bucher, E., Schweizerisches Obligationenrecht Algemeiner Teil ohne Deliktsrecht, Schulthess Polygraphischer Verlag, Zürich 1988, sh. 110; Eren, F., Borçlar Hukuku, Genel Hükümler Cilt 1, Sevinç Matbaası, Ankara 1991, sh. 284-285; Oğuzman, K.M.-Ö., T.M., Borçlar Hukuku Genel Hükümler, Istanbul 1995, sh. 46-47. 
ayncalıklan bulunmakıadır. Ancak diğer tüm idari sözleşmeler bakımından da tipik olan bu ozellik, her ne kadar ozel hukukta cari olan akit kavramından bir sapma gibi gözükse de aktin kurulus safhasındaki karşılıklı ve birbirine uygun iradelerin varlığı dolayısı ile, bir sőzleşme ilişkisinin varlığını engellememekte, hatta doktrin ve uygulamada idari sőzleşmelerin en karakteristik unsuru olarak kabul edilmektedir.

Bu nedenlerle biz, cebri tasarruf yaratılması ya da daha önceden kişi ve kurumlarca oluşturulmuş bulunan mevcut tasarruflara el konulması işlemini, Devletin hükümranlık gücüne dayanan, vergi benzeri bir kamusal tasarruf olarak görmekte ve bir borçlanma işlemi olarak kabul edilemeyeceğini düşünmekteyiz. Gerçekten, bir kıyas yapmak gerekirse; idarenin özel mülkiyetteki bir taşınmazı, bedelini ddeyerek kamulaştırması ne kadar satın alma sayılırsa, cebri borçlanmayı da o olçüde bir borçlanma saymak mümkündür.

Ülkemizde, Devlet ve öteki kamu tüzel kişilerince gerçekleştirilmiş olan borçlanmaların, yukarıda belirtilenlerin dışında, isteğe bağlı borçlanmalar biçiminde gerçekleştirildǐ̆i görülmektedir.

\section{IV. ÜLKEMIZDE KAMUSAL IÇ BORÇLANMALARIN GELIŞIMI}

Ülkemizde, Osmanlı Imparatorluğu Döneminde, Devlet tarafından başvurulan borçlanmalar genellikle dış borçlanma şeklindedir. Bu borçlanmalar ilk olarak 1854 yılında, Kırım Savışı sırasında gerçekleştirilmiş olup bu tarihten 1918 yılına kadarki borçlanmalar dış borçlanmalardır ${ }^{30}$. İç borçlanma yöntemi Osmanlı Imparatorlugu'nda ilk ve son olarak 1918 yılında; Birinci Dünya Savaşı'nın sonlarında denenmiştir. Devlet bu borçlanmayı $\% 4$ faizli ve 20 yıl vadeli olarak gerçekleştirmiş ve faiz ve anaparanın her türlü vergi ve resimden muaf olarak, alın karşıllı̆ında ödeneceği hükme bağlanmıştır ${ }^{31}$.

Cumhuriyet döneminde ise, Devlet tarafından ilk olarak, 14 Kasım 1933 tarih ve 2094 sayılı Kanunun verdił̧i yetkiye dayanılarak Fevzipaşa-Diyarbakır Demiryolu hattının yapımı amacı için iç borçlanmaya gidilmiştir. "1933 Ergani Istikrazı" olarak da adlandırılan bu borçlanmayı; 1934 yılında Sivas-Erzurum Demiryolu hatunın inşaası için yapılan "Sivas-Erzurum Istikrazı", 1938'de, Osmanlı Imparatorluğu döneminde 1918 yılında çıkarılmıs olan iç borç tahvillerinin konversiyonu amacıyla çıkarılmış olan "tkramiyeli 1938 Istkirazı" ve 1941 yılında Elazıg-Iran ve Diyarbakır-Irak sının Demiryolu hatlarının yapımı için çıkarılan "1941 Demiryolu Istikrazı" izlemiştir. Daha sonra 1942 yılında Ikinci Dünya savaşı nedeni ile artan milli savunma masraflarını karşılamak üzere başvurulan "Milli Savunma Istikrazı" ve 1946'da, hasılatı ekonomi kalkınması giderlerine harcanmak üzere başvurulan "Kalkınma Istikrazı"nı görmekteyiz.

1947 yılında, önceki yıllarda piyasaya sunulmuş olan hazine bonolarının konsolidasyonu amacıyla "1947 Hazine Tahvilleri" çıkarılmış ve yine aynı yıl, daha önce çıkarılan 11 Haziran 1945 tarih ve 4735 sayılı Çiftçiyi Topraklandırma Kanunu'nda, kamulaştınlan toprakların bedelleri karşılığında verilmesi öngörülmüş olan "Toprak

\section{${ }^{30}$ Arsan, a.g.e., sh. 18.}

31 Bkz. Yeniay, Hakkı. Osmanlı Borçları Tarihi, Ankara 1936, sh. 108. Ancak bu borçlanma girişimi I. Dünya Savaşının yarattığı olumsuzluklar nedeni ile çok fazla rağbet görmemiştir. Ayrıca bkz. Ince, a.g.e., sh. 63. 
Tahvilleri" çıkarılmaya başlanmışır ${ }^{32}$. 1948 yılından sonra ise ülkemizde ḥemen hemen her yıl bütçe açıklarının karşılanması ve yatırımların finansmanı amacıyla iç borçlanmalara gidildiği görülmektedir ${ }^{33}$.

\section{KAMU BORÇLANMA SÖZLEŞMELERININ HUKUKt NITELIĞI}

Devlet tarafindan hazine bonosu ya da devlet tahvili adı altında çıkanlan bu borçlanma senetlerinin ortak ozzelliği, hepsinin mutlaka ozel bir kanunla veya bir kanunun vermiş olduğu açık bir yetkiye istinaden çıkarılmıs olmalarıdır. Kanun, borçlanmanın hukuki rejimini de belirlemektedir ${ }^{34}$. Ömeğin, bu borçlanma senetlerine; vergi ve resimlerden muafiyet, haciz edilemezlik veya bazı hallerde para gibi kabulü zorunlu olmak gibi kamu gücünden kaynaklanan bazı ayrıcalıklar tanınabildiği gibi, bu senetlerin geri ödenmesi konusunda Devlet yönetimine de gene kamu imtiyazlanna dayanan bazı üstünlük ve ayrıcalıklar tanınabilmektedir ${ }^{35}$.

Cumhuriyet döneminde 1933 yılında yapılan ilk istikraz olan Ergani istikrazından 1948 yılına kadar Devlet idaresi tarafından yapılmış olan bütün istikrazların gelirleri her türlü vergi ve resimlerden muaf tutulmuştur ${ }^{36}$. Bunun gibi, bu istikraz senetlerine; Milli Emlak bedellerinin ödenmesinde para yerine kabulü zorunlu olmak ve kamu kurumlarnnca yapılacak ihale ve sözleşmelerde itibari kıymetleri üzerinden teminat olarak kabul edilmek gibi ayncalıklanın tanındığı görülmektedir ${ }^{37}$.

Ayrıca, Devlet yönetiminin de tek taraflı olarak bu borçlanmanın koşullannı değiştirebilme, Örneğin, konversiyon denilen faiz hadlerinin düşürülmesi, erken odeme yapılması ya da kısa vadeli borcun uzun vadeli borç haline dönüştürülmesi (konsolidasyon) gibi yetki ve ayrıcalıklarının bulunduğu kabul olunmaktadır ${ }^{38}$. Bu

32 Ayrntılı bilgilenme için bkz. Arsan, a.g.e., sh. 17-28.

${ }^{33}$ Ince, a.g.e., sh. 64; Kayla, Z., Merkez Bankası Işlemleri, Ankara 1981, sh. 101. Olkemizde geçmiş yıllarda; başka ülkelerde olduğu gibi Devlet tahvillerinin özel kişilerin birikmiş tasarrufları ile saun alınması yerine, daha çok kamu teşebbüsleri ve bankalarca satın alındığı görülmüştür. Böylece Hazinenin, sıkışık zamanlanında borçlanmak amacı ile genellikle kamu kuruluşlarına başvurarak hizine bonosu karşılığı ellerindeki olanakları kendisine devretmelerini istediği anlaşılmaktadır. Bkz. Kayla, a.g.e., sh. 102.

${ }^{34}$ Ince, a.g.e., sh. 24.

35 Onar, a.g.e., sh. 1611; Günday, a.g.e., sh. 137.

36 Arsan, a.g.e., sh. 31 ; Ince, a.g.e., sh. 66.

${ }^{37}$ Bkz. ek 1, lç Borçlanma Tahvili örneği, açıklamalar kısmı, Ayrıca bkz. Yaşa, a.g.e., sh. 59-60; Arsan, a.g.e., sh. 31.

${ }^{38}$ Nadaroğlu, a.g.e., sh. 252. Nitekim Devlet tarafından bu ayrıcalık ve imtiyazlara dayanılarak, çeşitli tarihlerde çıkarılan yasalarla, daha önceki borçlanmaların konversiyon ya da konsolidasyona tabi tutulduğu görülmektedir. Orneğin 22 Ocak 1938 tarih ve 3322 sayılı "Ikramiyeli 1938 Istikrazı" ile daha önce Osmanlı Imparatorluğu döneminde yapılan iç borçlanma tahvilleri konversiyona tabi tutulmuş ve yine 11 Haziran 1947 tarih ve 5072 sayılı Kanuna dayanularak çıkarılan 1947 Hazine Tahvilleri" ile ise daha önce 2 Haziran 1941 tarih ve 4060 sayılı Kanun ile çıkarılmıs olan hazine bonolarının konsolidasyonu gerçekleştirilmiştir. Bkz. Arsan, a.g.e., sh. 21, 25. 
nedenlerle; Devlet tarafından aktedilen tüm bu borçlanma sözleşmeleri, gerek yargısal içtihatlar ve gerekse doktrinimizde kurdukları ilişkinin ozelliği gereği (karakterleri itibariyla), idari nitelikte sözleşmeler olarak kabul edilmektedir ${ }^{39}$.

Kamu borçlanma sözleşmeleri bakımından dikkatleri çeken bir ozellik; diger idari sőzleşmeler bakımından da sőzkonusu olan, kaulmalı (iltihaki) işlem olma ozelliğinin 40 , kamu borçlanma sözleşmelerinde çok daha belirgin bir biçimde kendini gősterdił̌idir. Gerçekten de: örneğin, kamu hizmeti imtiyaz sözleşmeleri, idari hizmet sözleşmeleri ya da yer altı ve yer üstü servetlerine ilişkin işleme sözleşmeleri de bir katılmalı işlem; yani sőzleşmeci ozel kişilerin, genel olarak sözleşmenin hükümlerinin hazırlanmasında herhangi bir dahli olmadan, koşulları idarece tek taraflı olarak hazırlanmı olan bir sơzleşmeye katılması sureti ile gerçekleştirilen bir işlem olmalarına karşın, bu sőzleşmeler bakımından, hiç değilse sơzleşmenin mali hükümlerinin tarafların karşılıklı anlaşmaları sureti ile belirlenebileceği kabul edilmektedir. Oysa kamu borçlanma sözleşmelerinde sözleşmenin mali çerçevesi de devlet tarafından belirlenmekte ve bu konuda da sözleşmeci karşı tarafın iradesi etkili olamamaktadır. Devlet borçlanma amacı ile tahvil ya da bono çıkardığı zaman, sözleşmeci kişileri bütün hükümleri Devletin yetkili makamlarınca belirlenmiş olan bir sözleşmeye katılmaya (iltihaka) davet etmektedir. Bir diğer ifade ile, sözleşmenin karşı akidi konumundaki kişiler, şartları ve mali çerçevesi kanun tarafından ya da kanunun verdiği yetki çerçevesinde idarece belirlenmiş olan borçlanma senetlerini ya olduğu gibi kabul ya da reddetmek konumundadırlar. Bu sebeblerle ve ayrıca; borçlanmaya esas olan senetlerin genellikle hamiline yazılı olarak piyasalara arzedildikleri ${ }^{41}$ de göz önüne alındığında; kamu borçlanma sözleşmclerinin tip sözleşmelerin ${ }^{42}$ en tipik ơrneğini oluşturdukları sóylenebilir 43 .

\section{KAMU BORÇLANMA SÖZLEŞMEERINNDE YETKI SORUNU}

Ülkemizde, ilgili kanunlar çerçevesinde Devlet adına borçlanma yetkisi 1985 yılına kadar Maliye ve Gümrük Bakanlığı'na ait iken 44 , 1987 yılı Bütçe Yasasının 37/a maddesi ile bu yetkinin Hazine ve Dış Ticaret Müsteşarlı̆̆ı'na devredildiği ve daha sonra,

${ }^{39}$ Bkz. Danışıy Genel Kurulunun dipnot 12'de geçen kararı; Gözübüyük, A.Ş.. Tan, T., Idare Hukuku, Cilt I, Genel Esaslar, Ankara 1998, sh. 386, Balta, T.B., Idare Hukukuna Giriş I, Ankara 1970, sh. 192; Onar, a.g.e., sh 1612; Ayrica, genel olarak idari sözleşmeler ve bu sözleşmelerin ölçütleri konusunda bkz. Bilgen, P., Uyuşmazlık Mahkemesi ve Danıştay Içtihatlarına Göre Idari Sözleşmelerin Kriterleri, Istanbul 1970.

40"...hemen hemen tüm idari sözleşmelerin, katılmalı sözleşme şeklinde, ilkeleri ve çerçevesi daha önce üst makamlarca çizilmiş olarak gerçekleştiği ve ilgililere sadece ya sözleşmeyi olduğu gibi kabul etme ya da sözleşmeden vazgeçme seçeneklerinin bırakıldığı söylenebilir." Bkz. Erkut, C, Iptal Davasının Konusunu Oluşturma Bakımından Idari Işlemin Kimliği, Ankara 1990, sh. 39; Ayrıca bkz. Ozay, 1.H., Günı̧ı̆̆ında Yönetim, Istanbul 1996, sh. 414.

41 Arsan, a.g.e., sh. 30.

${ }^{42}$ Bkz. Ozay, a.g.e., sh. 414; Erkut, a.g.e., sh. 39.

${ }^{43}$ Bkz. Ekler kısmında. Başbakanlık Hazine Müsteşarlığınca çıkarılmıs olan Devlet ļ̧ Boçlanma Tahvili ömeği.

${ }^{44}$ Evgin, a.g.m., sh. 210. 
9 Aralık 1994 tarih ve 4059 sayılı, Hazine Müsteşarlığı ile Dı§̧ Ticaret Müsteşarlığı Teşkilat ve Görevleri Hakkında Kanun ile de Devlet adına iç borçlanma yetkisinin Hazine Müsteşarlı̆̆ı'na verildiğgi görülmektedir.

Sőz kenusu Hazine Müsteşarlığı ile Dış Ticaret Müsteşarlığı Teşkilat ve Görevleri Hakkında Kanun'un 452 nci maddesine gore: "...Devletin iç borçlanmasını yürüttmek, Devlet tahvili, Hazine bonosu ve diğer iç borçlanma senetleri çıkarmak, ihale yơntemi, suirekli satı̧̧ yőntemi ve diğer yöntemlerle sauş̧ını yapmak ve yapurmak, bunların satuş miktarlarını, değerlerini ve faizlerini belirlemek, Devlet borçlanının yönetimine ilișkin olarak her türlü iç borçlanmanın hazırlık, akit ihraç ve dış borçlanma da dahil olmak üzere odeme, erken odeme, kayıt işlemlerini yürütmek ve Devletçe verilen faiz ve ikrazata iliş̧kin işlemleri yapmak..." Hazine Müsteşarlı̌̆ı ana hizmet birimlerinden Kamu Finansmanı Genel Müdürlüğü'nün görevleri arasında sayılmaktadır.

Devlet dışındaki diğer kamu tüzel kişilerince ve ózellikle iktisadi kamu kurumlannca yapılan istikraz sözleşmeleri, esas itibari ile özel hukuk (medeni veya ticari bir borç) sözleşmesi niteliğindedir. Bununla birlikte, özel bir yasaya dayanılarak aktedilmeleri ya da sözleşmede kamu gücünden kaynaklanan üstünlük ve ayncalık hükümlerinin yer alması halinde bu sözleşmeler de idari nitelikte sayılırlar ${ }^{46}$.

Ülkemizde çeşitli tarihlerde çıkarılıan yasalarla Devlet dışında, Devlet Su Işleri Genel Müdürlüğüu, Tekel Genel Müdürlüğü, Devlet Demiryollan Genel Müdürlügüü, PTT Genel Müdürlügü, Karayollar Genel Müdürlüğü ve Istanbul Üniversitesi gibi çeşitli kamu tüzel kişilerine borçlanma yapma yetkisi verilmiştir.

Örneğin, PTT. Işletmesi Genel Müdürlüğüne iktisadi devlet teşekkülü haline dönüştürülmesinden önce, 3 Temmuz 1943 tarih ve 4454 sayılı Kanun'un 4740 . maddesi ile, bütçe kanunlannda göstcrilecek miktarlarda Maliye Bakanlığının kefaletiyle borçlanma yapma yetkisi verilmiştir. Aynı şekilde, 24 Ocak 1944 tarih ve 4516 sayılı 48 ve 11 Haziran 1947 tarih ve 5073 sayilı Kanunlarla Devlet Demiryollan Genel Müđürlüğüne hazine kefalctiyle bono çıkarma yctkisi verildiğini görmckteyiz. 18 Aralık 1953 tarih ve 6200 sayılı Kanun'un ${ }^{49} 2 / \mathrm{j}$ fikrası ile de Devlet Su Işleri Genel Müdürlüğüne, Maliye Bakanlığının muafakatı ve kefaleti ve Bakanlar Kurulunun karan ile uzun vadcli dış ve iç borçlanma yetkisi verilmiştir.

Yine, 3 Mart 1954 tarih ve 6344 sayılı Kanunla50 Karayolları Genel Müdürlüğ̈̈ne Bayındırlık Bakanlığının muafakati ve Maliye Bakanlığının kefaleti ile bono çıkarma yetkisi verilmiştir. Diğer taraftan, 27 Ocak 1947 tarih ve 4999 sayılı Istanbul Universitcsi Binalarının Yapımı Hakkında Kanun'un ${ }^{51}$ 1. maddesi ile de;

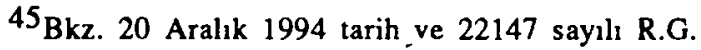

${ }^{46}$ Onar, a.g.e., sh. 1612.

${ }^{47}$ Bkz. 13 Temmuz 1943 tarih ve 5454 sayll R.G.

${ }^{48}$ Bkz. 1 Şubat 1944 tarih ve 5618 sayılı R.G.

${ }^{49}$ Bkz. 25 Aralık 1953 tarih ve 8592 sayılı R.G.

50 Bkz. 17 Mart 1954 tarih ve 8660 sayilı R.G.

${ }^{51}$ Bkz. 31 Ocak 1947 tarih ve 6520 sayli R.G. 
Istanbul Üniversitesi Hukuk ve Iktisat Fakültesi ile Fen ve Tıp Fakültelerinin ek bina inşaatlannda kullanılmak üzere Istanbul Ünversitesi Rektörlüğ̈̈ne bono çıkarma yetkisi ve bu bonolan kefalete de Maliye Bakanına yetki verilmiştir. Sozkonusu kuruluşlarca çeşitli tarihlerde çıkarılan Maliye Bakanlığının kefaletini haiz bonolarla iç ve dış istikrazlar yapılması yoluna gidilmiştir 52 .

Bunlann dışında, 1211 sayılı T.C. Merkez Bankası Kanunu'nda; Devlet, tktisadi Devlet Teşekkülleri ve iktisadi alanda faaliyet gősteren katma bütçeli idarelerin, T.C. Merkez Bankasi'ndan avans, kredi ve benzeri adlarla borçlanma yoluna gidebilecekleri hüküm aluna alınmaktadır. T.C. Merkez Bankası Kanunu' ${ }^{53}$ nun 21.4.1994 tarih ve 3958 sayılı Kanunla deł̧işik 50 nci maddesine göre; "Banka, her yıl cari yıl genel bütçe ¿denekleri toplamının, bir onceki mali yıl genel bütçe odenekleri toplamını aşan tutannın \% 12'sini geçmemek üzere Hazineye kısa vadeli bir avans hesabı açar. için \% 3'tür.

Bu oran, 1996 yılı için \% 10, 1997 yılı için \% 6, 1998 yılı ve müteakip yıllar

$\mathrm{Bu}$ avans hesabına uygulanacak faiz oranı her yıl ekonomik durum gozz onünde tutularak Başbakanlık ile Banka arasında kararlaştırılır."

Yine aynı Kanın'un 51. maddesine göre: "Banka, Iktisadi Devlet Teşekkülleri ile iktisadi alanda faaliyet gősteren katma bütçeli idarelerin hammadde ve mahsül alımı ile ilgili, mevsimlik ihtiyaçları için düzenleyecekleri en çok dokuz ay vadeli bonolann veya hazine kefaletini haiz bonolarını iskonto edebelir ve karşılığında avans verebilir....

Bu suretle kabul edilebilecek bonolann azami hadleri ile bunlara uygulanacak iskonto ve faiz hadleri banka meclisince kararlaşturılır."

Boylece, Devlet adına borçlanma yetkisinin kullanımında tek yetkili mercii konumunda olan Hazine Müşteşarlığı, iç borçlanmalarıni Merkez Bankası Kanununa dayanarak ve Bütçe Kanunularının verdiği yetki ölçüsünde gerçekleştirmektedir. Kamu Iktisadi Teşebbüslerinin iç borçlanmalan ise Hazine kefaleti ile ve kendi kuruluş kanunlarına dayanilarak gerçekleştirilmektedir ${ }^{54}$.

Hazine ve tktisadi Devlet Teşekküllerinin.Merkez Bankasından gerçekleştirdiği bu borçlanmalann yanında, yerel yönetimlerden belediyeler ve il özel idareleri de, merkezi yőnetimin gözetimi altında halktan ve piyasalardan borçlaṇma yoluna gidebilirler. 1580 sayılı Belediyeler Kanunu 55 70. maddesinin 5 . bendinde ikraz ve istikrazlar hakkında karar vermeyi belediye meclislerinin görevleri arasında saymaktadır. Bununla beraber Kanunda aktedilecek borçlanmanın konusu, miktan ve geri ödeme yöntemleri hakkında herhangi bir kısıtlayıcı hüküm yer almamaktadır. Bu durum karşısında belediyelerin yasanın kendilerine verdiği görevlerin yerine getirilmesi amacı ile kendilerine sağlanan

\footnotetext{
$52 \mathrm{Bu}$ borçlanmalarla ilgili aynntılı açıklamalar için bkz. Arsan, a.g.e., sh. 54 vd.

53 Bkz. 26 Ocak 1970 tarih ve 13409 sayrl R.G.

${ }^{54}$ Evgin, a.g.e., sh. $210,211$.

55 14.4.1939 tarih 1471 sayll R.G.
} 
gelir kaynaklarının yanı sıra, gerek tahvil çıkartmak suretiyle halktan, gerekse bankalardan borçlanma yapabilecekleri kabul edilmektedir 56 .

Aynca yine Belediye Kanunu'nun 19. maddesinin 10. bendine göre; münhasıran, tasdikli imar planlarının uygulanması dolayısı ile yapılacak kamulaşurma bedellerinin odenmesine ve kamulaşurmanın amacına veya imar planına uygun olarak yapılacak tesislerin meydana getirilmesine tahsis olunmak üzere, belediyelerce en çok (20) yılda itfa olunmak kaydı ile Türkiye Emlak Bankası'nın kefaleti ile tahvil çıkanlabileceği kabul olunmaktadir.

Son olarak, 1580 sayılı Belediye Kanunu'nun 131 ve 132 . maddeler ${ }^{57}$ ve fller Bankası Kanunu'nun ${ }^{58}$ 7/A maddesi çerçevesinde belediyelere, yine merkezî idarenin gőzetimi alında tller Bankasından iç borçlanma yapabilme imkanı da tanınmış bulunmaktadır. Günümüzde belediyeler daha çok bankalardan ve özellikle bu amaç için kurulmuş bulunan lller Bankasından borçlanma yoluna gitmektedirler ${ }^{59}$.

Yerel yönetimlerden il özel idarclcri ise, Il Özel Idaresi Kanunu'nun 131. maddesi çerçevesinde, bayındırlık, sağlık ve eğitim- øğretim hizmetlerinde harcanmak üzere borçlanma yoluna başvurabilirler. Il Özel ldaresi adına borçlanmaya karar verme yetkisi il genel meclisine aittir. Bununla birlikte il ozzel idarelerinin kontrolsüz bir oranda borçlanmalanını ónlemek amacı ile sıkı bir merkezi denetim öngörülmüş bulunmaktadır. Buna göre; mikıan, il ozel idaresi büçtesinde yazılı bir yıllık adi gelirlerin 1/3'ünü geçmeyen borçlanmalar bakımından, valinin teklifi üzerine il genel meclisinin karan yeterli iken; bu miktardan fazla, fakat toplamı il bütçesinde yazılı adi gelirlerin bir seneliğini aşmayan borçlanmalar bakımından, il genel meclisi karan ile yapılacak borçlanma sözleşmelerinin Bakanlar kurulunca tasdik edilmesi gerekmektedir. Bir veya birden fazla istikraz toplamının bir senelik adi gelirler toplamını aşması halinde ise kanun hükmü ile izin verilmesi şartı aranmışur ${ }^{60}$.

Tüm bu belintilen kuruluşlarca yapılan borçlanmalar uygulamada bir borçlanma sőzleşmesi şeklinde gerçekleştirilmektedir. Şoyle ki; örneğin belediyeler, kendi yapacaklan veya fller Bankası eliyle yapunimasın istedikleri kamu hizmetleri ile ilgili tesislerin yapımı için gerekli meblağdan kendi istikraz durumlarına göre belli bir miktan

56 Gunday a.g.e., sh. 335 .

${ }^{57}$ Belediye Kanunu madde 131 - "Her sene belediye bülçelerine mevzu varidatın safi miktan hesap edilerek bu saf ${ }_{1}$ varidatın yüzde beşi işbu kanunun neşri tarihini takip eden mali sene iptidasından itibaren yirmi sene müddetle aynı bütçeye ihtiyaç akçesi olarak vazolunacak ve belediyelere mahsus bir banka teessüs edinceye kadar hukümetin irae edeceği bir bankaya aynı mali senenin nihayetinden evvel tediye edilecektir." madde 132- "Belediye idareleri bankaya tevdi edilecek işbu meblağdan teraküm edecek miktarın yưzde yetmişbeşine kadar icap eden miktarın hersene butţesine tevfikan, ihtiyar edilecek imarat ve inşaat masraflan için sarfedilmek ve yine senesi içindeki belediye varidat ile odenmek uzere avans olarak bankadan istikraz edilebilirler..."

58 23.6.1945 tarih ve 6039 sayll R.G.

${ }^{59}$ Gunday a.g.e., sh. 336.

${ }^{60}$ Günday, a.g.e., sh. 320 . 
fller Bankasından borçlanabilmektedir ${ }^{61}$. Bunun için borçlanmak isteyen Belediye ilk Once bir yazı ile Bankaya müracaat etmekte ve bu müracaat ỉzerine fller Bankasının ilgili servisleri bu Belediyenin ne kadar ve ką sene vade ile borçlanabileceğini hesap ederek bu hususu Belediyeye bildirmektedir. Bu bildirimle birlikte fller Bankasınca belediyeye iki formül yollanır. Bu formülden birincisi, Belediye Kanununun 70. maddesinin 5. bendine göre; Belediye adına istikraz yapma yetkisi belediye meclisine ait olduğundan, Belediye meclisi adına kimin borçlanma senedini imzalamàya yetkili kılındığını gösteren karar orneğidir. Belediye meclisi toplanarak Belediye aclına borçlanma senedini imzalamaya yetkili kılınacak kişiyi tesbit eder. Bu kişi belediye başkanı ya da başka birisi olabilir. Meclisin bu kararının mahallin en büyük mülki amirine tasdik ettirilmesi gerekmektedir. Iller Bankası tarafından gönderilen ikinci formül iš borçlanma senedidir. Bu borçlanma senedinde borç miktan, bu borca uygulanacak faiz oranı, ödeme süresi ve vade tablosu Banka tarafindan doldurulmakta diğer bos kısımlar ise belediye yetkililerince doldurulup imzalanarak tller Bankasına gönderilmekte ve böylece Belediyenin borçlanma işlemi gerçekleştirilmektedir ${ }^{62}$. Doktrinde; her iki tarafı da idare olan bu borçlanma sőzleşmelerinin de idare hukuku rejimine tabi (idari) sözleşmeler olarak kabul edilebileceği, hakhı olarak ileri sürülmektedir ${ }^{63}$.

\section{IDARI SÖZLEŞMELERLEN DOGAN DAVALAR BAĞLAMINDA KAMU BOR:ÇLANMA SÖZLEŞMELERI}

Hukukumuzda, Devlet veya diğer kamu tüzel kişilerince gerçekleştirilen sőzleşmelerin idari sð̋zleşme niteliğinde kabul edilmesinin en önemli sonuçlarından biri: ozel hukuk sŏzleşmelerinden farklı olarak, bu sözleşmelerin uygulanmalarından kaynaklanabilecek uyış̧mazlıkların, adli yargıda değil, idari yargıda ve idare hukuku ilke ve kurallarına göre çozzümlenecek olmasıdır ${ }^{64}$. Nitekim, 2577 sayılı Idari Yargılama Usulü Kanunu'nun 2/1-c bendinde: "Genel hizmetlerden birinin yürütülmesi için yapılan her türlü idari sözleşmelerden dolayı taraflar arasında çıkan uyuşmazlıklara ilişkin davalar", idari dava türleri arasında sayılmakta ve idari sözleşmelerden doğacak davaların, idari yargı yerlerince ve idari yargılama usuline tabi olarak görüleceği hükme bağlanmaktadır.

Idari Yargılama Usulï Kanununun bu düzenlemesi ile ilgili olarak ilk bakışta dikkati çeken husus; maddenin lafzına sıkı sıkıya bağı kalarak hareket edilecek olunursa, kamu borçlanma sözleşmelerinden dolayı taraflar arasında çıkacak uyuşmazlıklara ilişkin davalann, IYUK. $2 / 1-c$ bendinde düzenlenen idari dava türleri arasında sayılamayacağ gibi bir sonucun ortaya çıkıyor olmasıdır. Çünkü 2577 sayılı Kanunun 2/1-c bendinde, "genel hizmelerden birinin yürütülmesi için yapılan idari sözleşmelerden" bahsolunmaktadır.

${ }^{61}$ Tortop, N., Mahalli Idareler, Ankara 1988, sh. 302.

${ }^{62}$ Tortop, a.g.e., sh. 303.

${ }^{63}$ Duran, Ders Notlan, sh. 428; Duran, Meseleler, sh. 222-225. Kural olarak bu görüşe katılıyor olmakla birlikte; aslında kamu borçlanma sözleşmelerinin, bilimsel bir tasnif çerçevesinde, idari sözleşmeleri de kapsamına alan "kamu hukuku sözleşmeleri" üst başlı̆̆ı altında ele alınıp, incelenmesinin daha doğru olacă̆ını dưşünmekteyim. Nitekim kamu borçlanma sözleşmeleri ile ilgili olarak bulabildiğimiz tek ömek olan Danıştay

Dava Daireleri Genel Kurulu kararında da, idari sözleşme kavramı hiç kullanılmadan,

"kamu hukuku kurallan ile vücut bulan" bir borçlanınadun söz edilmektedir.

${ }^{64}$ Gunday, a.g.e., sh. 134 . 
Oysa, kamu borçlanma sözleşmelerinin konusu bir kamu hizmetinin yürüttülmesi olmayıp, Devlet veya kamu tüzel kişilerince piyasalardan ya da gerçek kişilerden belli miktarlarda paranın ơdünç alınmasıdır. Nitekim bu sebebledir ki, kamu borçlanma sözleşmeleri hukukumuzda "karakterleri (kurduklan ilişkinin niteliģi) itibarı ile" idari saylmaktadır.

Şüphesiz böylesine bir yorum, kamu borçlanma sözleşmelerinin idari sözeşme sayılmalarını engellemeyeceği gibi; bu sózleşmelerden doğacak davalann idari bir dava olarak çozümlenmesine de engel teşkil etmeyecektr. Nitekim hukukumuzda, konulan bir kamu hizmetinin yürütülmesi ya da bir kamu hizmetinin yürütülmesine kaulma olmamasına rağmen, maden işletme ve orman işletme sőzleşmelerinin idari sőzleşmelerden olduklanı ve bunlardan dolayı taraflar arasında çıkacak uyuşmazlıkların idari yargıda çőzümleneceği konusunda bir tereddüt bulunmamaktadır ${ }^{65}$.

Bu durumda, kamu borçlanma sözleşmelerinden doğacak davalan, fYUK.'nun 2/1-b bendi çerçevesinde bir tam yargı davası şeklinde nitelendirmek gerekecektir. Ancak, belirtmek gerekir ki; IYUK.'nun 2/1-c bendinde idari sözleşmelerden doğan davalar ayrı bir dava türü olarak düzenlenmiş olmasına karşın, bütün idari sơzleşmeler bakımından bu sőzleşmelerin yapılmasından sonra taraflar arasında çıkacak uyuşmazlıkların, ayrılabilir işlemler dışında, esas itibanyła bir tam yargı davası şekilde görüleceği kabul edildiği için ${ }^{66}$, pratikte, tYUK.'nun 2/1-c maddesinin düzenlenişinden kaynaklanan bir hukuksal niteleme sorununun ortaya çıkmayacağı söylenebilir.

\section{SONUÇ}

Bir kamu finansman yöntemi olarak borçlanma, günümüzde Devletlerin yıllık bütçe açıklanını kapatmak için baş vurduklan, olağan bir yönetim halini almışur. Devlet ve diğer kamu tüzel kişileri ihtiyaç duyduklan paraları "Devlet Tahvili" ya da "Hazine Bonosu" gibi adlarla çıkardıklan senetler vasitasıyla tıpkı bzel kişiler gibi halktan ve piyasalardan borç almak sureti ile de temin edebilmektedir. Borçlanmada kural, kişi ve kuruluşların serbest iradeleri ile Devlet ve diğer kamu tüzel kişilerine borç vermeleridir. Zorunlu borçlanmalar dışında, kamu borçlanmalanı taraflann karş̧ıkılı iradesine dayandığı için, bir sőzleşme ilişkisinden sőz etmek mümkündür. Sőz konusu borçlanma sőzleşmeleri hukukumuzda "kamu borçlanma (istikraz) sőzleşmeleri" olarak adlandırılmaktadır. Doktrinde genel olarak, zorunlu (cebri) borçlanma olarak adlandırılan durumlarda ise, esas itibarıyla sözleşme ilişkisinin temel unsuru olan, serbest ve karşılıklı iradelerin birleşmesinden söz edilemeyeceğinden, bu gibi durumlarda bir sőzleşme ve dolayısı ile borç ilişkisinin varlığının sőzkonusu olmaması gerekir. Bu gibi

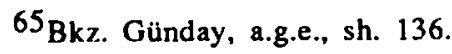

${ }^{66}$ Uler, Yıldırım. "Sözleşmeli Personel Idari Sözleşmeler", AUHFD., Cilt 22, sayı 1, sh. 233-234; Gözübüyük, S..-Dinçer, G., Idari Yargılama Usulu, Ankara 1996, sh. 144; Gözübuyuuk, S., Yőnetsel Yargı, Ankara 1993, sh. 198-199; Aynca bkz. IYUK madde 36; Bununla birlikte; Danıştay, idari sözleşmelere karşı ilgililerce açılan iptal davaların da kabul ederek karara bağlamaktadır. Ön.: D. 12-D; 2.11 .1976 gün ve E.1974/1958, K.19762141 say1l karar, D.D. 26-27, sh. 509; D.10.D; 29.4.1993 gün ve E.1991/1., K. 1993/1752 sayılı kararı, D.D. 88, sh. 463 vd. Bkz. Yenice, K.-Esin, Y., Açıklamalı Içtihatlı Notlu Idari Yargılama Usulu, Ankara 1983, sh. 122 vd.; Ayrica Fransız Danıştayının bu konudaki karar ve yaklaşımları ile ilgili olarak bkz. Gözübüyuk, \$., Tan, T., a.g.e., sh. 416.417. 
durumlarda olsa olsa Devletin vergi benzeri bir kamusal tasarrufundan sőz edilmesi daha yerinde olacaktur.

Devlet ve diğer kamu tüzel kişilerince aktedilen borçlánma sözleşmeleri, pek çok açılardan ozel kişiler arasindaki sözleşmelerden farklılık göstermektedir. Kamu borçlanma sơzleşmelerinde sőzleşme konusu seneulere; haczedilememek, Devlet ihalelerinde teminat olarak ve bazı durumlarda para yerine kabul edilme zorunluluğu gibi ayncalıklar tanınabileceł̧i gibi, ozel hukuk sőzleşmelerinden farklı olarak, bu sőzleşmelerin süresini uzatmak, faiz hadlerini değiştirmek ve erken odeme yapmak gibi imtiyaz ve ayrıcalıklarının oldı̆̆u da kabul edilmektedir. Bı nedenlerle kamu borçlanma sözleşmeleri, gerek yargısal içtihatlanmızda ve gerekse doktrinde, kurduklan ilişkinin niteliłł̆i gereği olarak (karakterleri itibarıyla) idari sరozleşmelerden sayılmaktadır. Kamu borçlanma sőzleşmelerinin idari nitelikte sözleşmelerden sayılmalanını én onemli sonucu ise, bu sözleşmeler dolayısı ile idare ile özel kişiler arasında çıkacak uyuşmazlıkların idari yargıda ve idare hukuku ilke ve esaslanna göre çözüınlenıccek olmasıdır.

\section{KA YNAKÇA}

Arsan, Üren, Türkiye'de Cumhuriyet Devrinde $\mathbb{k}_{\zeta}$ DŁvvlet Borçları, Sevinç Matbaası, Ankara 1961.

Balta, Tahsin Bekir, Idare Hukukuna Giriş I, Sevinç Matbaașı, Ankara 1970.

Bilgen, Pertev, Uyuşmazlık Mahkemesi ve Danıştay Içtihatlarına Göre Idari Sözleşmelerin Kriterleri, Kurtuluş Matbaassı, Istanbul 1970.

Bucher, Eugen, Schweizerisches Obligationenrechl: Allgemeiner Teil, Schulthess Polygraphischer Verlag, Zürch 1988.

Duran, Lütfi, Idare Hukuk Ders Notları, Fakülteler Matbaası, Istanbul 1982.

Duran, Lütfi, Idare Hukuku Meseleleri, Fakülteler Matbaası, Istanbul 1964.

Eren, Fikret, Borçlar Hukuku, Genel Hükümler, Cilt I, Sevinç Matbaası, Ankara 1991.

Erginay, Akif, Kamu Maliyesi, Ankara 1981.

Erkut, Celal, Iptal Davasının Konusunu Oluşturma Bakımından Idari Işlemin Kimlił̌i, Danıştay Matbaası, Ankara 1990.

Evgin, Tülay, "90'lı Yıllarda Iç Borçlanımızın Ekonomik Açıdan Değerlendirilmesi", A.Ü. SBFD., Prof. Dr. Latif Çakıcı'ya Armağan, Ocak-Haziran 1995, No: 1-2, sh. $209-220$.

Günday, Metin, Idare Hukuku, Zirve Ofset, Ankara 1996.

Gøzübüyük, Şeref-Dinçer, Güven, Idari Yargılama Usulü, Cantekin Matbaası, Ankara 1996.

Gözübüyük, Şeref - Tan, Turgut, Idare Hukuku, Cilı I, Genel Esaslar, Ankara 1998. 
Gozzübüyüik, Şeref, Yơnetsel Yarg1, Adalet Matbaası, Ankara 1993.

Ince, Macit, Devlet Borçlanması (Kamu Kredisi), Adalet Matbaacıllk, Ankara 1996.

Kayla, Ziya, Merkez Bankası Işlemleri, Ankara tktisadi ve Ticari tlimler Akademisi Yayınlarn No: 149, Ankara 1981.

Nadaroğlu, Halil, Kamu Maliyesi Teorisi, Istanbul 1985.

Onar, Sıddık Sami, Idare Hukukunun Umumi Esaslan, Ismail Akgün Matbaası, Istanbul 1966.

Oğuzman, Kemal M.-Öz, Turgut M., Borçlar Hukuku Genel Hükümleri, Fakülteler Matbaası, Istanbul 1995.

Özay, Il Han, Günışığında Yönetim, Alfa Basım Yayım Dağıtım, Istanbul 1996.

Tortop, Nuri, Mahalli Idareler, tlk-San Matbaası, Ankara 1988.

Ozer, tlhan, Devlet Maliyesi, Cilt II, Başbakanlık Basımevi, Ankara 1980.

Uler, Yıldırım, "Sözleşmeli Personel Idari Sözleşmeler", AÜHFD., Cilt 22, sayı 1, sh. 215-228.

Yaşa, Memđuh, Devlet Borçlan, \̧̧ Matbaacılık ve Ticaret, Ankara 1978.

Yayla, Yıldızhan, Idare Hukuku I, Bayrak Matbaacilık, Istanbul 1990.

Yeniay, Hakk, Osmanlı Borçlan Tarihi, Mehmet thsan Matbaası, Ankara 1936.

Yenice, Kazım-Esin, Yüksel, Açıklamalı-lçtihatlı-Notlu ldari Yargılama Usulü, Arısan Matbaacılık ve Ambalaj Sanayii, Ankara 1983.

Dâva Daireleri Umumi Heyeti

E : $38 / 375$

K : 44/54

Dâvact : Istanbul Basiret Han No. 24 ve avukat Abdülhak Kemal Yörük.

Dâva edilen: Maliye Vekâleti.

Dâvanın $H: 3 / 4 / 1934$ - 1911 sayılı kanun mucibince ihraç olunan \% 5 faizli istikrazı dahiliyeye ait muvakkat senedattan elinde bulunan 304498 numarah muvakkat senedin katî bir tahvil ile mübadelesi akkındaki müracaatuna Maliye Vekâletince hâdisede Borçlar Kanununun kabul ettiği müruru zaman haddi geçiğinden bahsile red cevabı verilmiş ise de istikrazı dahilî senedatı Devlet ile fert arasında münakit hususi bir mukaveleye müsteniden ihrą̧ olunup bu mukavelede muvakkat senetlerin katî senetle 
mübadelesi için 15 sene bir müddet tâyin ve tesbit olunduğu Borçlar Kanununun 125 inci maddesi ise hiç bir vę̧hile 3/4/1918 tarihli kanun ahkâmını tağyir edemiyeceği; kaldı ki Borçlar Kanununun 125 inci maddesi ise nihayet akitlerin sakıt kaldıklan hususlarda cereyan etmesi lâzım gelen müruru zaman müddetlerine kabili tatbik olup dahili istikrazda ise muvakkat senetlerin kati senetlerle mübadelesi için kabul edilmiş olan müddet kanundan değil mukaveleden münbais olduğu ve bu mukaveleden taraflardan olan Devletin selâhiyettar unsurlarının ahkâmın tesbit ederek iltihaka davet ettikleri bir mukavele oldư̆u cihetle alâkadarların bu mukavele ankâmından tamamen istifadeleri icabeylediği ve hâdisede istikraz âdi bir istikraz olmadığı cihetle hukuku hususiye meselesi olarak kabul edilemiyeceğinden dâva edilenin vazife itirazının reddiyle istikrazı dahilî muvakkat senedinin katî senetle mübadelesine karar verilmesi mealindedir.

Dava edilenin müadefaası $H$ : thtilâf Devlctle fert arasındaki bir mukaveleden doğan hakkın müruru zaman ile sukut edip etmediğine müteallik olmasına ve akitten doğan bir hakkın müruru zamana uğramış olup olmadığını tetkik ve halletmek umumi muhakemelerin kaza salâhiyetine dâhil mesail cümlesinden bulunmasına binaen dâvnın vazife noktasından reddi icabedeceği.

Esasa gelince; Hükümetle ferdi bağlayan rabıta hususi bir mukaveleden doğmakta olduğundan her mukavelede olduğu gibi bu mukavelenin de zaruri olarak hususi hukuk prensiplerini tanzim ve idare eden kanunların şümul ve tefsirine tabi olması lâzım gelecȩ̧i ve intizan âmme olamıyacağı ve müruru zamanda intizamı âmme meselesinden oldugundan artuk bu hususta mukavele ile tesbit edilen müruru zamana değil yeni kanun olan Borçlar Kanununun koyduğu müruru zaman hükmünün tatbiki icabedeceği ve tatbikat kanunda müruru zamnun bilcümle hükümlerinin Kanunu Medeninin meriyetinden itibaren bu kanun hükmüne tabi olacağını tasrih ettiği, bu hüküm karşısında mukavelede o zamanki ahkâma mütenazır olarak kabul olunan müruru zaman hükmüne itibar olunmıyacağı; bilhassa istikraza vücut veren kanun müruzu zamana mütaallik hususi kanuna uygun olduğ takdirde muteber olacağı ve kanunun değişmesi zaruri olarak mukaveleye tesir edeceği taraflardan biri Hükümetten ise mukavele serbestisini haiz olmadıkları bir husus hakkında hükmü mahsus derpiş etmiş olmaları kanun nazarında tamamen hükümsüz olduğundan dâvanın reddi mcrkezindedir.

Müddeiumuminin Mütalâası : Dâva 918 sàylı kanun mucibince ihraç olunan istikrazı dahilî muvakkat senetlerinden müddeinin elinde bulunan 304498 sayılı muvakkat senedin katî tahvil ile değiştirilmesi hakkında talıbinin dâva edilen idare tarafından müruru zaman iddiariyle reddedilmiş olmasına itirazdan ibarettir.

Devletin umumi bir istikraza müracaat etmek suretiyle giriştiği faaliyet ile fevkalâdeden bütçeye vadirat temin etmesi hukuku âmme meselesidir. Bunlarda daha hükümet ile istikraza kayıt edilenler arasında akdi bir münasebet ve ancak şartları Devletçe tesbit ve ilân edilmiş olan istikrazlara yazılıp yazılmamak efradın serbest irade ve arzusuna bırakılmakta ve bu suretle istikraza kajłt anından itibaren hükümetle istikraza kayıt olunan fert arasında tamamen hususi hukuk sahasına giren bir akit münasebetini vücut bulmaktadır.

Dâva mevzuu muvakkat senedin tebdili hususundaki ihtilâf dahi bu istikraz muamelesinin fert ile hükümet arasında hususi hukuk sahasına dâhil olan muamelelere ve mukavelenin tatbikına taallûk ettiğinden tetkik ve rüyeti adli kazaya ait olduğu ve Devlet Şûrasının vazifesi haricinde bulunduğu mütalâa kılınmakıadır. 


\section{TÜRK ULUSU ADINA} düşïnüldü:

Hüküm veren Devlet Şûrası Dâva Daireleri Umumi Heyeti tarafından işin gereği

Devlet istikrazlan hukuku âmme kavaidiyle vücut bulan bir borç olmak itibariyle bundan mütevellit ihtilâfların tetkiki hususunun Devlet Şûrasının vazifesi dâhilinde bulunduğuna ve istikrazın tabi olduğu statüde tahvilâtı katiyenin ihracı tarihinden itibaren on bes sene zarfında ibraz edilmeyen muvakkat senedatun hazine lehine müruru zamana ự̆rayacağı̆ yolundaki kayıt, hususi bir sukutu hak müddeti olup bunun ahkâmı umumiye ile takyidi caiz olamıyacağına binaen muvakkat senedin borçlar kanuniyle mevzu on senelik müruru zamandan bahsile kat̂ tahvili ile tebdil edilmemesi yolundaki muterezünbih muamelenin iptaline ve peşin ödenmiş yüz kuruşun müddeiye iadesine 400 kuruş ilâm harcının müddeaaleyhden tahsiline ve celp edilen tahvillerin mahalline iadesine 11/4/1944 tarihinde ekseriyetle karar verildi. 


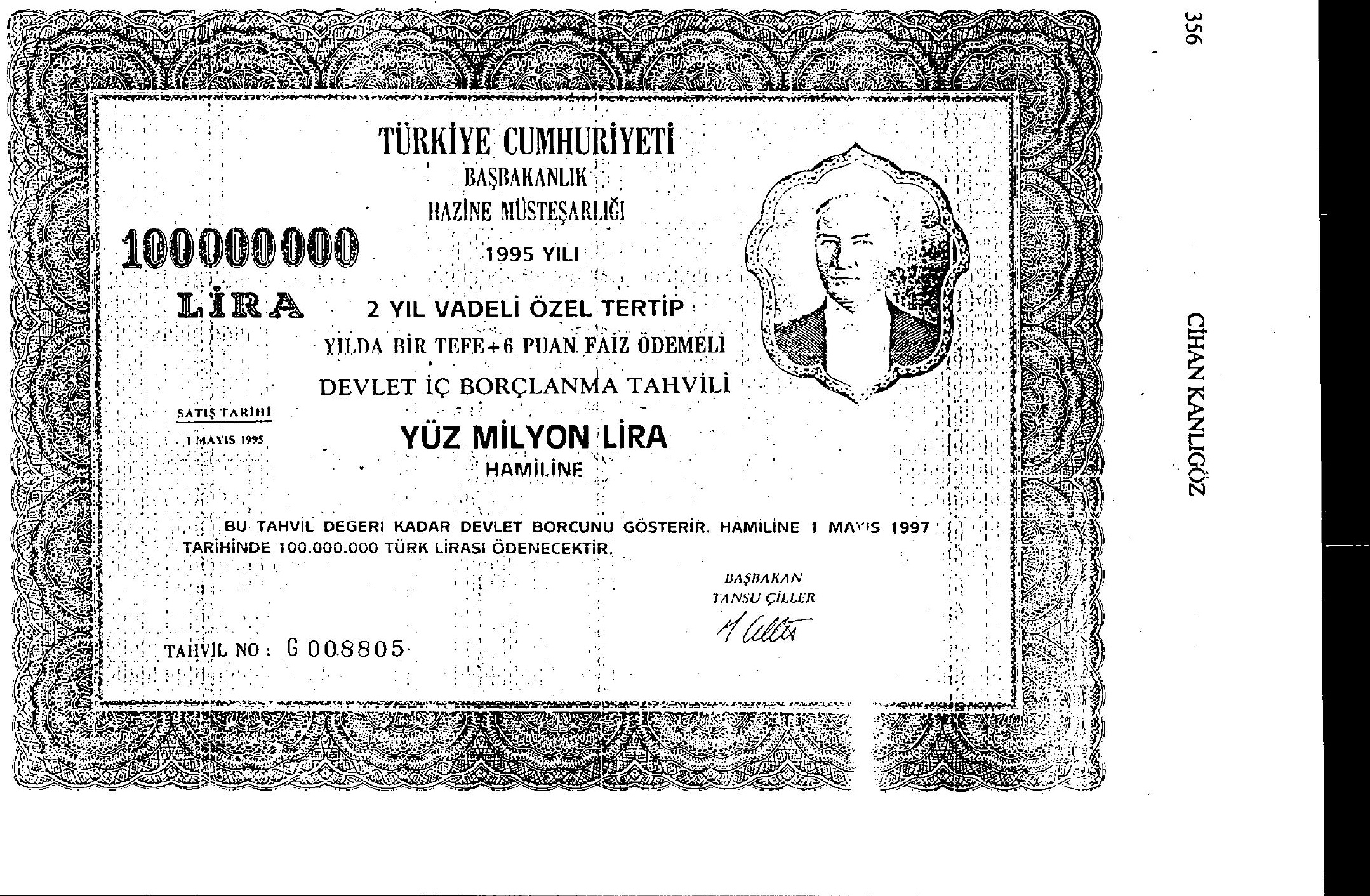




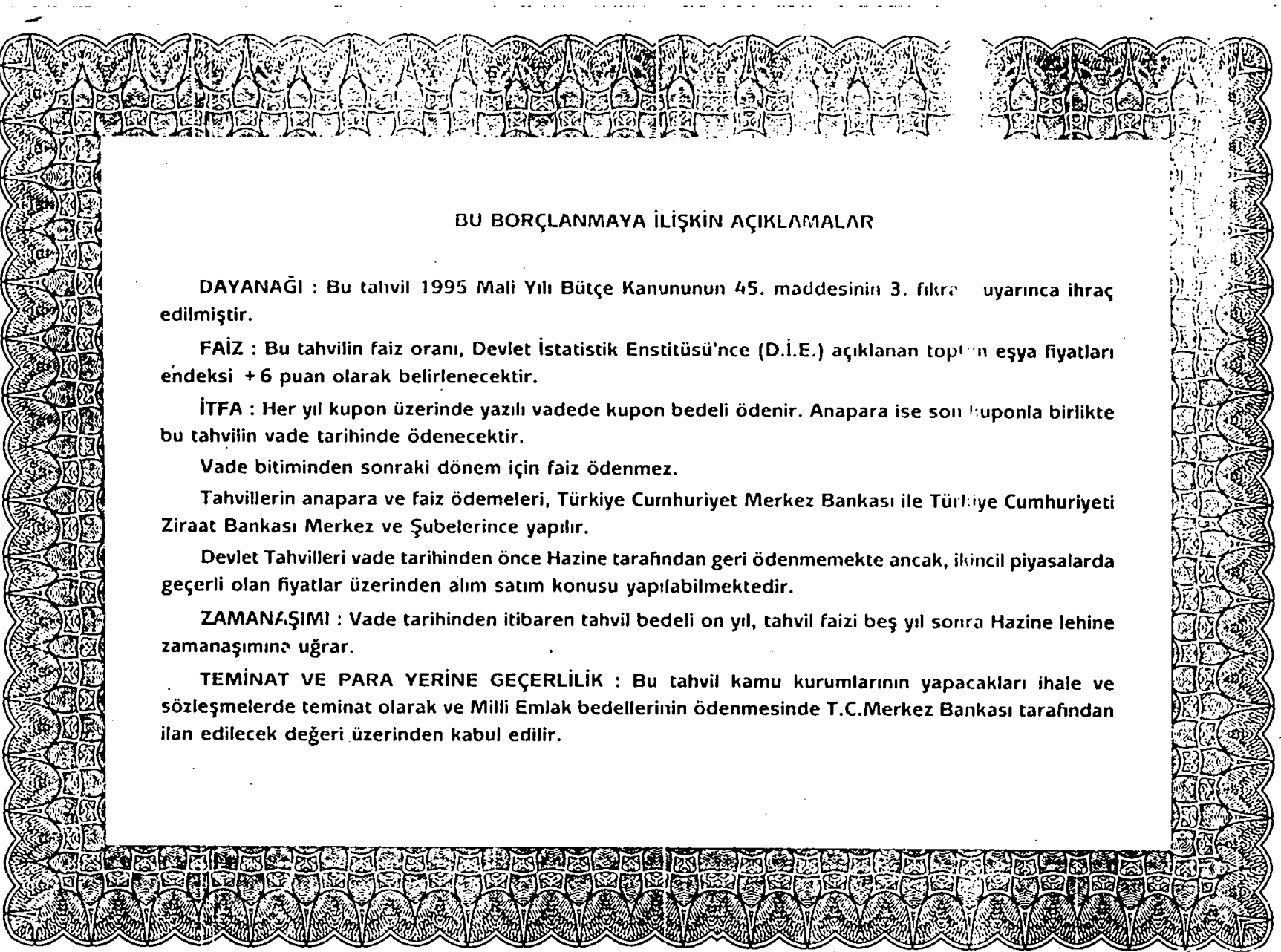

